quire approximately 2,000 feet of shelf space; the same volumes reproduced in ultramicrofiche could be contained in six small card trays that would fit easily on an ordinary bridge table. Ultramicrofiche is similar to microfiche, the form of document storage and retrieval now in wide use in government and industry. However, microfiche generally contains only 60 to 100 images per card; the ultramicrofiche can contain up to 3,000 images in the same space, at reductions of $150 \mathrm{X}$.

With the use of a UMF reader, the image is projected from inside the reader onto a viewing screen at normal, or slightly larger-than-normal, page size. The user is able to find and read one image at a time by moving the fiche until identifying coordinates are located, or he can browse through the pages, referring to the page numbers displayed on the screen. Maxinum usefulness will be assured by the creation of special retrieval and research tools. These include catalogs in four forms-magnetic tape, book form, ultramicrofiche, and standard catalog cards-based on Library of Congress classifications, as well as speciallyconstructed topical bibliographies and research guides. UMF has the potential of providing every student and faculty member with his own portable reader. In the future, a student may be able to acquire a sizable library of selected titles in a package no larger than a standard dictation machine, complete with reader and ultramicrofiche, weighing less than five pounds.

Some 20,000 volumes will be represented in the first library in the series, The Library of American Civilization, Beginnings to 1914, to be published in the fall of 1970. The UMF Library of American Civilization will range over all aspects of America's culture, treating every field. It will cover every period of American life and literature up to 1914 , and will include all points of view-from those of the framers of the Constitution to those of the Indians, Negroes, Mexicans, Orientals, and other groups that have played important parts in the shaping of American society. Future UMF Libraries from Britannica will include collections on Medieval Civilization, English History, International Affairs, Science, Technology and Art. Content of the Britannica UMF Libraries will not include material from the Encyclopaedia Britannica itself.

With the basic Britannica UMF Library of American Civilization, and with each subsequent library in the series, an institution will receive the ultramicrofiches, five sets of book-form catalogs, five sets of book-form bibliographies and research guides, and 20 sets of ultramicrofiche catalogs. Magnetic tape catalogs and standard card catalogs are optional items. Reading and reproduction equipment will be purchased direct from the manu- facturer. Britannica will be conducting seminars at various locations across the country over the next several months to provide college officials with demonstrations of the ultramicrofiche technology and to give details of the first library in the Britannica series.

- The publication of the Catalogue of Hebrew Books of the Hanvard UnIversity library was celebrated October 23,1968 , at a reception held in the Widener Memorial Rooms. Professor Harry A. Wolfson, Nathan Littauer Professor of Hebrew Literature and Philosophy, Emeritus, and Honorary Curator of Hebraica and Judaica in the Harvard College library, was presented a copy of the Catalogue in recognition of his role as founder of the collection some forty years ago. The publication of the six-volume Catalogue, a photographic reproduction in book form of the 75,000 cards in the library's Hebrew Card Catalogue, is a major event in Hebrew bibliography, and the Catalogue is an invaluable reference tool for students and scholars throughout the world.

- The academic libraries section of the South Dakota Library Association has just published its South Dakota Union List of Serials. This union list serves as a finding tool for periodical and serial holdings in fifteen public and private colleges and universities. The 521 pages of the document were prepared through the use of the IBM $1130 \mathrm{com}-$ puter system. Libraries interested in purchasing copies may write to James L. Dertien, Norman B. Mears Library, Sioux Falls College, Sioux Falls, S.D. It is available unbound for $\$ 12.00$.

\section{VERNER CLAPP HONORED}

News comes from Tokyo that Verner IV. Clapp, LC's chief assistant librarian in 194756 and President of the Council on Library Resources in 1956-67, has been awarded an Order of the Sacred Treasure by the Government of Japan. The National Diet Librarian, Yoshikatsu Kono, presented Mr. Clapp with the magnificent gold and silver medal and the handsome scroll that accompanies the award in ceremonies at the NDL on November 12, while Mr. and Mrs. Clapp were guests of the NDL durin: their recent visit to Japan to attend the dedication ceremonies of the NDL. The Orders of the Sacred Treasure were instituted in eight classes in 1888 for men and women who have rendered "excellent services" to Japan. The honor was awarded to Mr. Clapp-now Consultant, Council on Library Resources, Inc.-in recognition of his contributions to the planning and development of the National Diet Library in 1947-48. 